\title{
A Novel Factor Xa-Inhibiting Peptide from Centipedes Venom
}

\author{
Yi Kong $\cdot$ Yu Shao $\cdot$ Hao Chen $\cdot$ Xin Ming $\cdot$ \\ Jin-Bin Wang $\cdot$ Zhi-Yu Li $\cdot$ Ji-Fu Wei
}

Accepted: 5 June 2013/Published online: 19 June 2013

(c) The Author(s) 2013. This article is published with open access at Springerlink.com

\begin{abstract}
Centipedes have been used as traditional medicine for thousands of years in China. Centipede venoms consist of many biochemical peptides and proteins. Factor $\mathrm{Xa}(\mathrm{FXa})$ is a serine endopeptidase that plays the key role in blood coagulation, and has been used as a new target for anti-thrombotic drug development. A novel FXa inhibitor, a natural peptide with the sequence of Thr-Asn-Gly-TyrThr (TNGYT), was isolated from the venom of Scolopendra subspinipes mutilans using a combination of sizeexclusion and reverse-phase chromatography. The molecular weight of the TNGYT peptide was 554.3 Da measured by electrospray ionization mass spectrometry. The amino acid sequence of TNGYT was determined by Edman
\end{abstract}

Y. Kong $(\bowtie) \cdot$ Y. Shao $\cdot H$. Chen

School of Life Science \& Technology, China Pharmaceutical

University, 24 Tong Jia Xiang, Nanjing 210009,

People's Republic of China

e-mail: yikong668@163.com

\section{Y. Kong}

State Key Laboratory of Natural Medicines,

China Pharmaceutical University, Nanjing 210009,

People's Republic of China

\section{Ming}

Division of Molecular Pharmaceutics, UNC Eshelman School of Pharmacy, The University of North Carolina at Chapel Hill, Chapel Hill, NC 27599, USA

J.-B. Wang - Z.-Y. Li

School of Pharmacy, China Pharmaceutical University, 24 Tong

Jia Xiang, Nanjing 210009, People's Republic of China

\section{J.-F. Wei $(\square)$}

Research Division of Clinical Pharmacology, The First Affiliated Hospital with Nanjing Medical University, 300 Guangzhou

Road, Nanjing 210029, China

e-mail: weijifu@hotmail.com degradation. TNGYT inhibited the activity of FXa in a dose-dependent manner with an $\mathrm{IC}_{50}$ value of $41.14 \mathrm{mg} /$ $\mathrm{ml}$. It prolonged the partial thromboplastin time and prothrombin time in both in vitro and ex vivo assays. It also significantly prolonged whole blood clotting time and bleeding time in mice. This is the first report that an FXa inhibiting peptide was isolated from centipedes venom.

Keywords Scolopendra subspinipes mutilans venom . FXa inhibitor · Peptide $\cdot$ Anticoagulation

\section{Introduction}

Centipedes (Scolopendra subspinipes mutilans L. Koch) are predatory, elongated and dorsoventrally flattened arthropods, which belong to the Chilopod class (Negrea and Minelli 1995). In China, centipedes have been used for thousands of years as a traditional Chinese medicine for treating the diseases, such as stroke-induced hemiplegia, apoplexy, epilepsy, tetanus, whooping cough, tuberculosis, scald burns, and pyocutaneous disease. Especially, they have been prescribed for treating cardiovascular diseases in Korea, China and other countries in East Asia for several hundred years (Pemberton 1999).

Centipede venoms were released from the venom glands connecting to the first pair forceps to kill prey and defend against its predators (Rates et al. 2007). The venoms are a natural pool of proteins, peptides and enzymes with a rich variety of biologic activities. Recent studies have showed that centipede venoms contain more than 500 proteins and peptides with the following pharmacological properties: platelet aggregating activity, anticoagulant activity, phospholipase A2 activity, trypsin inhibiting activity, voltage-gated potassium channel activities, voltage-gated sodium channel activities, 
voltage-gated calcium channel activities (Liu et al. 2012; Yang et al. 2012).

Coagulation factors are the main targets for anti-thrombotic drug development (Simkhada et al. 2012). Among these coagulation factors, Factor Xa (FXa), which is a serine endopeptidase, plays the key role in the blood coagulation, because it functions at the convergence point of the extrinsic and intrinsic pathways for blood coagulation (Gan et al. 2009). There have been reports of discovery of FXa inhibitors by isolating proteins or peptides from natural sources, since antistasin, a 119-amino acid protein, was isolated from the salivary glands of the Mexican leech Haementeria officinalis in 1987 (Dunwiddie et al. 1989). A 60-amino acid anticoagulant peptide was purified from extracts of the soft tick Ornithodoros moubata and was shown to inhibit FXa only (Waxman et al. 1990). In another report, a FXa-inhibiting peptide called Draculin was isolated from the saliva of Vampire bats (Desmodus rotundus) (Fernandeza et al. 1999). In addition, Ac-AP-12 (Jiang et al. 2011), Nymphal FXa inhibitor (Batista et al. 2010), and AduNAP4 (Gan et al. 2009) are the peptides with FXa inhibiting activity. However, FXa inhibitor has not been isolated from centipede venom.

In this study, we isolated a novel peptide, with the sequence of TNGYT, from S. subspinipes mutilans venom, which can inhibit FXa activity. Moreover, this peptide was shown to resist coagulation with in vitro assay and in mice. To our best knowledge, this is the first report demonstrating that a peptide purified from centipede venom can inhibit FXa activity.

\section{Materials and Methods}

\section{Materials}

Adult S. subspinipes mutilans L. Koch (both sexes, $n=1,000$ ) was purchased from Qiancheng centipede breeding field (Jinhua, Zhejiang Province, China).

Sephadex G-50 was obtained from Pharmacia (Uppsala, Sweden). Purified human FXa and chromogenic substrate of FXa (S2222) were purchased from HYPHEN BioMed (Neuvile sur Oise, France). Mice of both sexes were from Qinglongshan animal center (Nanjing, Jiangsu Province, China). All the animal protocols were approved by the Animal Care and Use Committee at China Pharmaceutical University. All other chemicals and reagents were at analytical grade.

\section{Venom Extraction}

Venom was collected manually by stimulating the venom glands in the first pair forceps of centipedes using the multi-purpose electrical instrument with the frequency at $7.8 \mathrm{~ms}$ (i.e. $128 \mathrm{~Hz}$ ), the voltage at $10-20 \mathrm{~V}$, and the pulse width at 2-4 ms. Each milking occurred 1 week after the previous milking. Venoms were stored at $-20{ }^{\circ} \mathrm{C}$ until further use.

Anticoagulant Peptide Purification

The collected venom $(0.5 \mathrm{~g})$ was diluted in $20 \mathrm{ml}$ phosphate buffered saline (PBS, pH 6.0), and then centrifuged at $10,000 \mathrm{rpm}$ for $8 \mathrm{~min}$. The supernatant was applied to a SephadexG-50 column $(26 \mathrm{~mm} \times 100 \mathrm{~cm})$, equilibrated with PBS (pH 6.0) and eluted with the same buffer at a flow rate of $0.6 \mathrm{ml} / \mathrm{min}$. The fractions were collected at $10 \mathrm{~min}$ intervals. The absorbance of the elutes was monitored at $214 \mathrm{~nm}$. The fractions were pooled according to the absorbance. The activated partial thromboplastin time (aPTT) and prothrombin time (PT) were evaluated for each fraction. The fraction 2 which showed prolonged aPTT and PT activities was further separated by reverse-phase high performance liquid chromatography (RP-HPLC) (Bio-Rad Duoflow System, USA) on a Lichrospher C18 column $(10 \mathrm{~mm} \times$ $250 \mathrm{~mm}$; Hanbon, China) with a linear gradient elution conditions using acetonitrile as the organic modifier and trifluoroacetic acid (TFA) as the volatile buffer. Eluent A consisted of $0.1 \%$ TFA in $10 \%$ acetonitrile $(\mathrm{v} / \mathrm{v})$, eluent $\mathrm{B}$ of $0.1 \%$ TFA in $90 \%$ acetonitrile (v/v). Gradient elution was carried out according to the following process: $0-10 \mathrm{~min}, \mathrm{~B}$ $0 \% ; 10-50 \mathrm{~min}, \mathrm{~B} 0-100 \%$. The flow rate was at $1 \mathrm{ml} / \mathrm{min}$. The UV absorbance was monitored at $214 \mathrm{~nm}$. The fractions that prolonged aPTT and PT (2-6) were collected and further purified by another C18 column $(4.6 \mathrm{~mm} \times 250 \mathrm{~mm}$; Hanbon, China) eluted as the same condition above. The main peak was pooled and stored at $-20{ }^{\circ} \mathrm{C}$.

Determination of Molecular Mass and Peptide Sequence

1The molecular mass of the purified peptide was determined by electrospray ionization mass spectrometry (ESI-MS) (Agilent6500, Agilent, USA) with the following conditions: $\mathrm{ESI}^{+}$ion source, spray voltage was $3,500 \mathrm{~V}$, fragmentator voltage was $120 \mathrm{~V}$, capillary temperature was $365^{\circ} \mathrm{C}$, the pressure of ESI nebulizing gas $\left(\mathrm{N}_{2}\right)$ was $275.79 \mathrm{kPa}(40 \mathrm{psi})$, and the flow rate of drying gas $\left(\mathrm{N}_{2}\right)$ was $10.00 \mathrm{l} / \mathrm{min}$. Complete peptide sequencing was performed using Edman degradation method on an Applied Biosystems pulsed liquid-phase sequencer, model 491.

Peptides Synthesis

The peptide used for the following bioactivity assays was synthesized by the Fmoc ( $N$-[9-fluorenyl]-methoxycarbonyl) 
chemistry in solid-phase synthesis. Usually, peptides are synthesized from the carbonyl group side (C-terminus) to amino group side ( $\mathrm{N}$-terminus) of the amino acid chain. The solid supports were preloaded with 2-chlorotrityl chloride resin for C-terminal acid in this synthesis. Protected amino acids were coupled by in situ activation with diisopropylethylamine (DIEA) and $N$-hydroxybenzotriazole (HOBt). Then dimethylformamide (DMF) with $20 \%$ piperidine was performed in deprotection for $20 \mathrm{~min}$. Cleavage of the peptide from the resin was performed by reagent $(95 \% \mathrm{TFA} / 2.5 \%$ triisopropylsilane (TIS) $/ 2.5 \%$ water) for $1 \mathrm{~h}$. The peptide was purified by preparative reverse-phase HPLC on a C 18 column $(20 \times 250 \mathrm{~mm})$. Elution was performed using a linear gradient $(0-50 \% \mathrm{~B}$ in $20 \mathrm{~min})$ of $0.1 \%$ TFA in $10 \%$ acetonitrile (A) and $0.1 \%$ TFA in $90 \%$ acetonitrile (B) at a flow rate of $2 \mathrm{ml} / \mathrm{min}$. The absorbance was monitored at $214 \mathrm{~nm}$. The main peak was pooled, dried in vacuum, lyophilized, and stored at $-20^{\circ} \mathrm{C}$. The purity was analyzed by HPLC and ESI-MS.

\section{PT and aPTT Clotting Assays}

Blood was drawn by Eyeball from ICR mice. The blood was separately centrifuged at $2,500 \times g$ for $10 \mathrm{~min}$ to obtain platelet poor plasma (PPP). For the in vitro aPTT assay, normal citrated PPP $(50 \mu \mathrm{l})$ was incubated with sample solution $(8,6,4,2,1 \mathrm{mg} / \mathrm{ml}$, previously diluted in PBS, $\mathrm{pH}$ $8.34,50 \mu \mathrm{l}$ ) and $100 \mu \mathrm{l}$ aPTT reagent for $3 \mathrm{~min}$ at $37{ }^{\circ} \mathrm{C}$. Clotting time was immediately recorded after the addition of $100 \mu \mathrm{l}$ of $20 \mathrm{mM} \mathrm{CaCl}_{2}$. For the in vitro PT assay, normal citrated PPP $(25 \mu \mathrm{l})$ was incubated with sample solution $(8,6,4,2,1 \mathrm{mg} / \mathrm{ml}$, previously diluted in PBS, $\mathrm{pH}$ $8.34,25 \mu \mathrm{l}$ ) for $3 \mathrm{~min}$ at $37^{\circ} \mathrm{C}$. Clotting time was immediately recorded after the addition of $50 \mu \mathrm{l}$ of PT reagent (Majdoub et al. 2009). All coagulation assays were performed in triplicates. Heparin was used as a positive control, and PBS ( $\mathrm{pH}$ 8.34) as model control. For ex vivo coagulation assays, samples were dissolved in saline and were intravenously injected (10 or $20 \mathrm{mg} / \mathrm{kg}$ ) in ICR mice (6 animals/group). Five and $24 \mathrm{~h}$ after drug administration, blood was collected (drawn by eyeball), immediately centrifuged (3,000 rpm, $15 \mathrm{~min})$, and the plasma was used to measure the aPTT and PT as previously described (Batista et al. 2010).

\section{Clotting Time In Vivo}

Whole blood clotting time (CT) in mice was measured by capillary glass tube method (Li et al. 2004). Mice (18-22 g body weight) were divided into four groups (both sexes, six per group). Two groups were received intravenous injection of 20 and $10 \mathrm{mg} / \mathrm{kg}$ body weight of the purified peptide for four consecutive days. Other groups were received normal saline and $20 \mathrm{mg} / \mathrm{kg}$ body weight of heparin (the positive control), respectively. Fifteen minutes after the last administration (positive control after $2 \mathrm{~h}$ ), blood samples were collected through the retro-orbital plexus with a glass capillary and kept on a slide to allow for clotting. Stirring the blood with a dry needle every $30 \mathrm{~s}$ until needle wire can provoke a fibrous protein, when is defined as clotting time.

\section{Bleeding Time In Vivo}

The mice (both sexes, 18-22 g) were randomly divided into four groups. The samples were intravenously injected (10 or $20 \mathrm{mg} / \mathrm{kg}$ ) in ICR mice (6 animals/group) once a day in four consecutive days. Fifteen minutes after the last administration (positive control after $2 \mathrm{~h}$ ), the mice tail was marked with a tag in the distance of $3 \mathrm{~mm}$ to after peak, then cut in the mark. Then the tip of the tail was immersed in saline at $37^{\circ} \mathrm{C}$. Record the time from cutting the tip of the tail to stopping bleeding, the interval was called bleeding time (Kogushi et al. 2011). Heparin was used as positive control, and $0.9 \%$ saline as model control.

\section{FXa Inhibition Assay}

Chromogenic substrate method was used to measure the FXa-inhibiting activity. Inhibition was determined by FXa residual activity on the chromogenic substrate BIOPHEN CS-11 (S-2222) (22), which liberates the chromophoric group pNA (p-nitroaniline) (van Wijk and Smit 1984). Different concentrations of the peptide $(5-60 \mathrm{mg} / \mathrm{ml})$ were incubated with FXa for $30 \mathrm{~min}$ at $37{ }^{\circ} \mathrm{C}$ in PBS (pH 8.34). The reaction was initiated by adding the substrate into the peptide solution (Ibrahima et al. 2001). The absorbance at $405 \mathrm{~nm}$ was recorded every $0.5 \mathrm{~min}$ in $5 \mathrm{~min}$. In A-t curve, the curve slope was considered as reaction rate (v). Inhibition rate $(\%)=\frac{\mathrm{V}_{0}-\mathrm{V}_{\mathrm{i}}}{\mathrm{V}_{0}} \times 100 \%, \mathrm{~V}_{0}$ is the rate of PBS (pH 8.34, model control), and $\mathrm{V}_{\mathrm{i}}$ is the rate of peptide.

\section{Molecular Docking}

To study the FXa inhibition mechanism of the peptide, Molecular Operating Environment (MOE, version 2009.10) was applied to predict how the peptide interacts with FXa (PDB ID: 2UWP). The good docking was determined using Molecular Mechanics Generalized Born Interaction Energy (MM/GBVI) in the MOE software. The MM/GBVI represents non-covalent interactions between the receptor and the ligand including the van der Waals energy, coulomb energy, and generalized Bonn implicit solvent interaction energy (Labute 2008). 


\section{Statistical Analysis}

Data are shown as mean \pm SE for the number of experiments indicated, and ANOVA followed by Tukey's tests were used for statistical comparison of the data. In all analyses, $P<0.1$ (or $P<0.01$ ) was considered as statistically significant.

\section{Results}

Purification of the Peptide

The crude venom was separated into six fractions by Sephadex G50 column (Fig. 1a). Fractions 1, 2 and 3 showed aPTT and PT activity. Fraction 2 was then separated by RP-HPLC on a Lichrospher C18 column (Fig. 1b). Fraction 2-6 showed aPTT and PT activity. This active fraction was then purified by another $\mathrm{C} 18$ column (Fig. 1c) to give the final purified peptide.

Determination of Molecular Mass and Peptide Sequence

The molecular mass of the purified peptide was determined to be $554.3 \mathrm{Da}$ by ESI-MS (Fig. 2) and the primary structure was identified as Thr-Asn-Gly-Tyr-Thr (TNGYT) by Edman degradation. The molecular mass of TNGYT by ESI-MS matched the theoretical molecular mass (554.6 Da) deduced from amino acid sequence of TNGYT. By BLAST (http://blast.ncbi.nlm.nih.gov/) search, the peptide showed no similarity with any other known peptides or proteins in S. subspinipes mutilans (taxid: 251420). Although a few proteins from Streptococcus parasanguinis and Leptosphaeria maculans contained the fragment TNGYT, there was no single peptide fragment as TNGYT in the protein or peptide database.

Peptides synthesis

All peptides used for the following bioactivity assays were synthesized by the Fmoc ( $N$-[9-fluorenyl]-methoxycarbonyl) chemistry in solid-phase synthesis. The synthesized peptides were purified by RP-HPLC. The main peak was pooled (Fig. 3). The purity was higher than $95 \%$ analyzed by HPLC. It was identical to the natural one confirmed by ESI-MS.

We utilized MS/MS to confirm the sequence of the synthetic peptide. As we expected, the result indicated that the synthetic peptide has the sequence of TNGYT (Fig. 1 in the Supplementary Data). Then, we compared the biological activity of the natural peptide and the synthesized peptide using aPTT and PT assays. The result indicated that the two peptides have the same biological activity (Table 1 in the Supplementary Data).

\section{Assay of aPTT and PT of TNGYT}

For in vitro coagulation assays, TNGYT prolonged the aPTT and PT in a dose-dependent manner. It can prolong the aPTT clot time from 33.3 to $57 \mathrm{~s}$ and PT clot time from 12.7 to $23.3 \mathrm{~s}$, respectively, at the concentration of $8 \mathrm{mg} /$ $\mathrm{ml}$ (Table 1). The action of TNGYT was lower than the positive control heparin $(1 \mathrm{mg} / \mathrm{ml})$.

For ex vivo coagulation assays, when the mice were treated with 10 or $20 \mathrm{mg} / \mathrm{kg}$ TNGYT, no significant alterations were observed in the PT. However, increases in the aPTT were observed in both 5 and $24 \mathrm{~h}$ after drug administration (Table 2).

\section{Clotting Time In Vivo}

In comparison with the control group, 20 and $10 \mathrm{mg} / \mathrm{kg}$ TNGYT group could significantly prolong whole blood clotting time $(P<0.01)$ as positive control heparin did. This indicated that TNGYT had anticoagulant effects. (Table 3).

\section{Bleeding Time In Vivo}

Compared to the model control group, 20 and $10 \mathrm{mg} / \mathrm{kg}$ TNGYT groups could significantly prolong the bleeding time $(P<0.01)$. At equal dose $(20 \mathrm{mg} / \mathrm{kg})$, the bleeding time of heparin was longer than that of TNGYT (Table 4). It implied that the risk of bleeding by TNGYT treatment was lower than that of heparin.

\section{FXa Inhibition Assay}

As shown in Fig. 4, TNGYT inhibited the activity of FXa in a dose-dependent manner with an $\mathrm{IC}_{50}$ of $41.14 \mathrm{mg} / \mathrm{ml}$. TNGYT at a concentration of $60 \mathrm{mg} / \mathrm{ml}$ could inhibit FXa activity by $59.75 \%$.

\section{Molecular Docking}

FXa contains a deep S1 pocket and a box-like S4 pocket at the active site. S1 pocket consists of Asp189, Ser195 and Tyr228 residues while S4 consists of Tyr99, Phe174 and Trp228 residues. Potential FXa inhibitors usually bind to both $\mathrm{S} 1$ and S4 pockets which are connected in L-shape (Rai et al. 2001). As shown in Fig. 5, it was found that TNGYT binds to Asp189, Ser195 and Tyr228 residues of $\mathrm{S} 1$ and Tyr99 residue of $\mathrm{S} 4$ at the MM/GBVI value of $-17.696 \mathrm{kcal} / \mathrm{mol}$. This docking result supported the result 
Fig. 1 Purification of TNGYT from centipede venom. a $S$. subspinipes mutilans venom was separated by Sephadex G-50 column. b The faction 2 after Sephadex G-50 column was separated by RP-HPLC on a C18 column. c The fraction C-3 after RP-HPLC on a C18 column was separated by another C18 column. The final purified peptide was designated as TNGYT
A
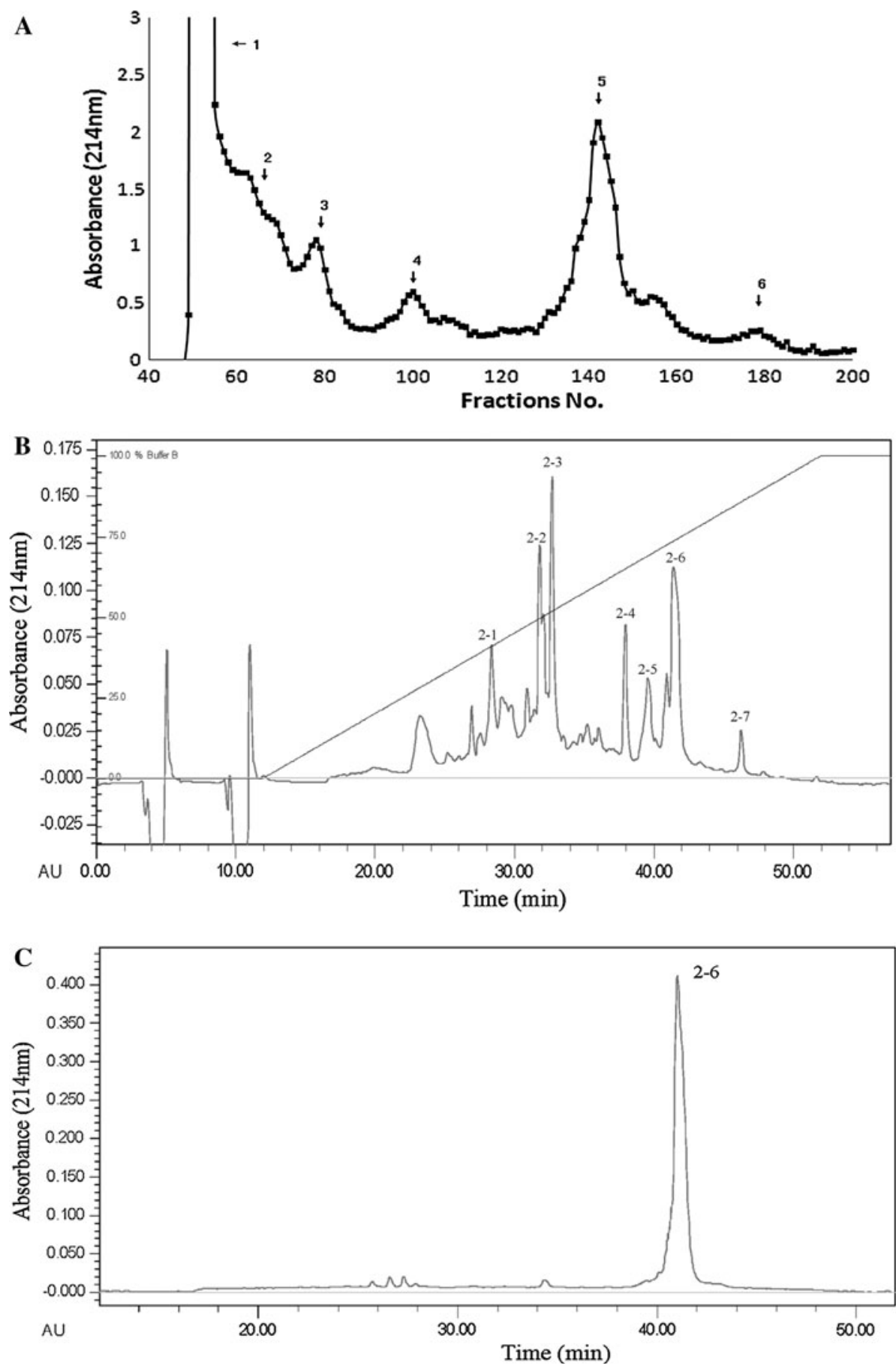

of FXa inhibition assay and confirmed that TNGYT is an FXa inhibitor.

\section{Discussion}

The centipede contains many bioactive components, including 5-hydroxytryptamine, histamine, lipids, polysaccharides, and various enzymes (e.g. proteinases and esterases) (Knysak et al. 1998; Gomes et al. 1983). They have been widely used as traditional folk medicine to treat thrombotic diseases in China (Pemberton 1999) for several hundred years. You et al. (2004) isolated a $25 \mathrm{kDa}$ serine protease from $S$. subspinipes mutilans, which demonstrated fibrinolytic activity by converting human Glu-plasminogen to activated plasmin. Wu et al. (2009) found centipede acidic protein (CAP) significantly suppress the development of atherosclerosis, improved the hemorrheological disturbances and histopathological changes in the atherogenic diet fed rat model. We previously isolated an anti-thrombotic peptide with primary structure of peptide is 
Fig. 2 The molecular mass of TNGYT determined by ESIMS. The molecular mass of purified TNGYT is $554.3 \mathrm{Da}$

Fig. 3 Purification of the synthetic TNGYT. The synthetic peptide solution was further purified by RP-HPLC on a preparative-scale $\mathrm{C} 18$ column (a). The purity of synthetic TNGYT was confirmed by ESIMS (b)
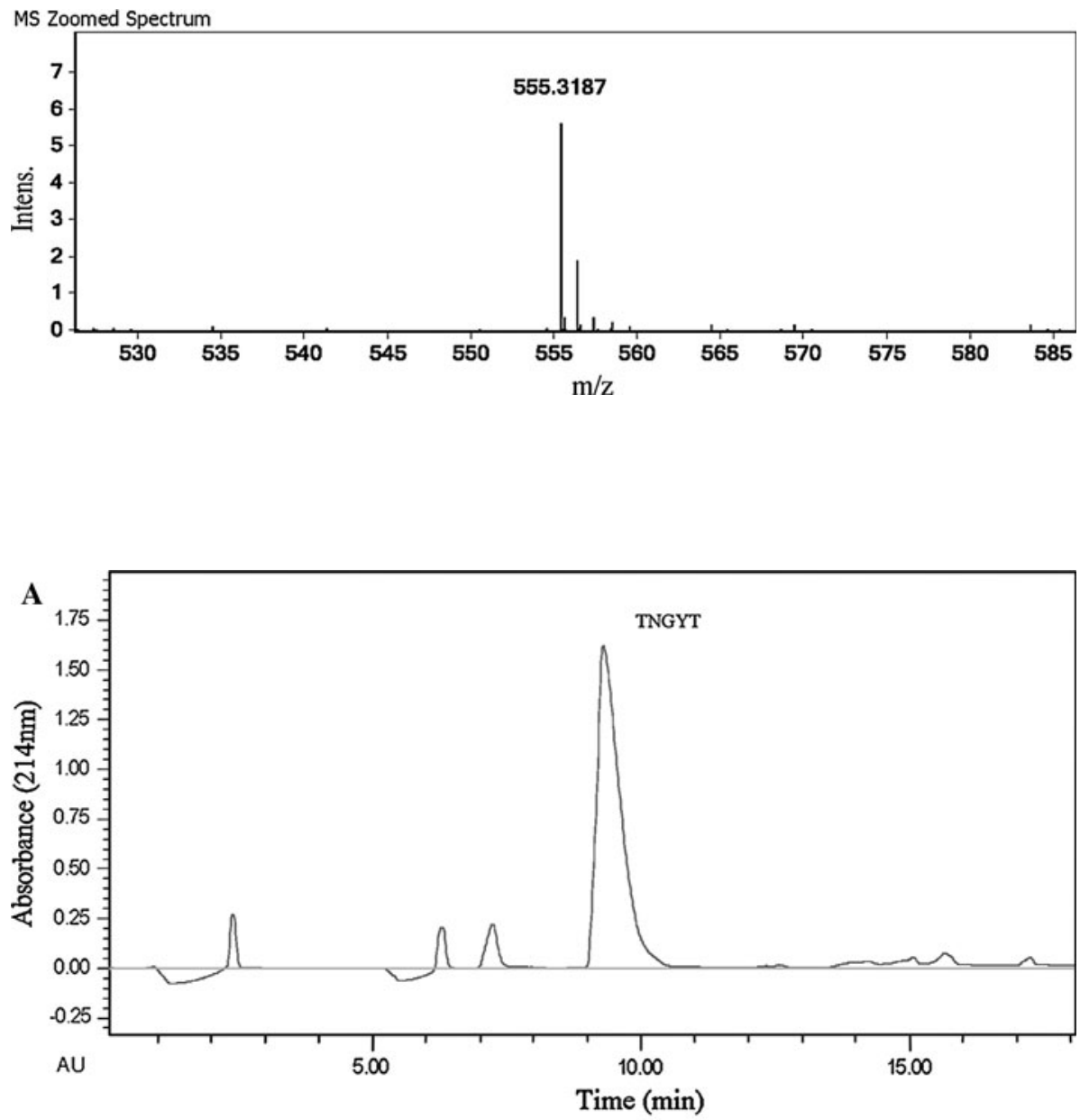

B MS Zoomed Spectrum

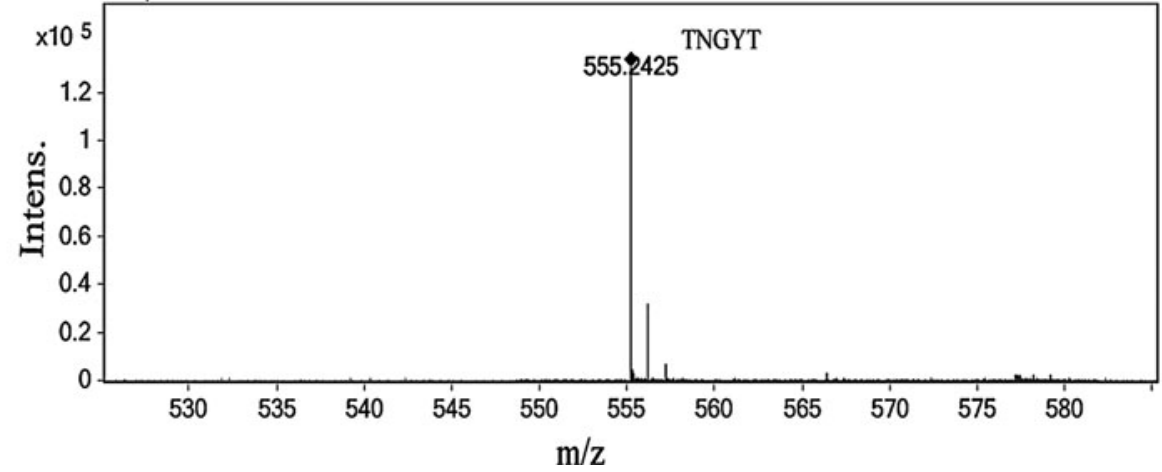

Ser-Gln-Leu (SQL) from S. subspinipes mutilans (Kong et al. 2013).

Centipede venoms contain a variety of different components with diverse functions (Mohamed et al. 1983). Ren et al. (2006) isolated an antibacterial peptide named scolopendrin I from the venom of S. subspinipes mutilans. González-Morales et al. (2009) isolated a phospholipase $\mathrm{A}_{2}$ from the venom of $S$. viridis Say. Peng et al. (2010) reported the structural and functional characterization of two antimicrobial peptides (scolopin 1 and -2) identified from the venoms of $S$. subspinipes mutilans. Rates et al.
(2007) identified more than 60 proteins/peptides in $S$. viridicornis nigra and $S$. angulata venoms by a proteomic approach. Liu et al. (2012) further purified and characterized 40 proteins/peptides from crude venom of $S$. subspinipes dehaani. The purified proteins/peptides showed different pharmacological properties, including platelet aggregating, anticoagulant, phospholipase $\mathrm{A}_{2}$, trypsin inhibiting, voltage-gated potassium channel, voltage-gated sodium channel, and voltage-gated calcium channel activities. Yang et al. (2012) identified 26 neurotoxin-like peptides from the venom of $S$. subspinipes mutilans. In the 
Table 1 APTT and PT assay in vitro

\begin{tabular}{llll}
\hline $\begin{array}{l}\text { Concentration } \\
(\mathrm{mg} / \mathrm{ml})\end{array}$ & Sample & APTT $(\mathrm{s})$ & PT (s) \\
\hline 0 & $0.9 \%$ saline & $33.3 \pm 1.5$ & $12.7 \pm 1.2$ \\
1 & Heparin & $>60.0^{* *}$ & $>60.0^{* *}$ \\
1 & TNGYT & $36.7 \pm 1.5^{*}$ & $14.7 \pm 0.6^{*}$ \\
2 & TNGYT & $44.0 \pm 2.0^{* *}$ & $15.3 \pm 1.5^{*}$ \\
4 & TNGYT & $44.0 \pm 1.0^{* *}$ & $17.7 \pm 0.6^{* *}$ \\
8 & TNGYT & $57.0 \pm 2.0^{* *}$ & $23.3 \pm 1.5^{* *}$ \\
\hline
\end{tabular}

$* * P<0.01, * P<0.1$, compared with $0.9 \%$ saline

Table 2 APTT and PT assay ex vivo

\begin{tabular}{lllll}
\hline $\begin{array}{l}\text { Time } \\
(\mathrm{h})\end{array}$ & $\begin{array}{l}\text { Dose } \\
(\mathrm{mg} / \mathrm{kg})\end{array}$ & Sample & APTT (s) & PT (s) \\
\hline 5 & 0 & $0.9 \%$ saline & $49.0 \pm 3.6$ & $15.7 \pm 1.5$ \\
& 10 & TNGYT & $59.0 \pm 2.0^{*}$ & $16.7 \pm 0.6$ \\
& 20 & TNGYT & $65.7 \pm 3.1^{* *}$ & $18.0 \pm 1.0^{*}$ \\
24 & 0 & $0.9 \%$ saline & $47.0 \pm 1.0$ & $17.7 \pm 0.6$ \\
& 10 & TNGYT & $49.3 \pm 1.5^{*}$ & $18.7 \pm 1.5$ \\
& 20 & TNGYT & $51.3 \pm 2.3^{*}$ & $18.3 \pm 0.6$ \\
\hline
\end{tabular}

$* * P<0.01, * P<0.1$, compared with $0.9 \%$ saline

Table 3 Effect of TNGYT and TGNYT on clotting time in mice

\begin{tabular}{lll}
\hline Code & Sample & CT (s) \\
\hline Model control & $0.9 \%$ saline & $273.2 \pm 38.6$ \\
Positive control & Heparin $(20 \mathrm{mg} / \mathrm{kg})$ & $718.8 \pm 60.15^{* *}$ \\
TNGYT $(10 \mathrm{mg} / \mathrm{kg})$ & TNGYT $(10 \mathrm{mg} / \mathrm{kg})$ & $389.0 \pm 35.74 * *$ \\
TNGYT $(20 \mathrm{mg} / \mathrm{kg})$ & TNGYT $(20 \mathrm{mg} / \mathrm{kg})$ & $463.0 \pm 48.8^{* *}$ \\
\hline
\end{tabular}

$* * P<0.01$, compared with model control $(0.9 \%$ saline $)$

Table 4 Effect of TNGYT and TGNYT on bleeding time in mice

\begin{tabular}{lll}
\hline Code & Sample & BT (s) \\
\hline Model control & $0.9 \%$ saline & $315.2 \pm 33.4$ \\
Positive control & Heparin $(20 \mathrm{mg} / \mathrm{kg})$ & $804.3 \pm 87.7 * *$ \\
TNGYT $(10 \mathrm{mg} / \mathrm{kg})$ & TNGYT $(10 \mathrm{mg} / \mathrm{kg})$ & $447.5 \pm 78.1^{* *}$ \\
TNGYT $(20 \mathrm{mg} / \mathrm{kg})$ & TNGYT $(20 \mathrm{mg} / \mathrm{kg})$ & $549.7 \pm 60.9^{* *}$ \\
\hline
\end{tabular}

$* * P<0.01$, compared with model control ( $0.9 \%$ saline $)$

present study, the pentapeptide TNGYT was isolated from $S$. subspinipes mutilans by a combination of gel filtration and reverse-phase HPLC.

Generally, the venoms from some snake, parasitic and blood-feeding animals, such as snake, tick, bat and leech are considered rich resource to discover new anticoagulant agents. Han et al. (2008) purified an anticoagulant serine protease named as magnvesin from the wasp venom of Vespa magnifica. Xu et al. (2000) isolated two

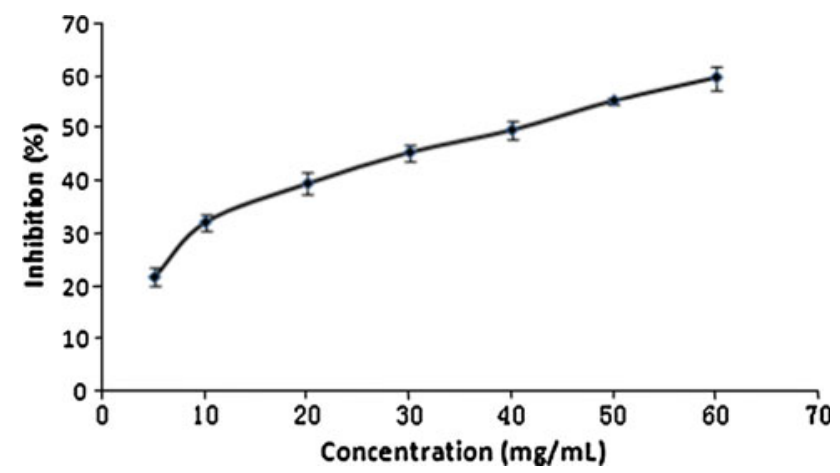

Fig. 4 FXa inhibition curve of TNGYT. TNGYT inhibited the activity of $\mathrm{FXa}$ in a dose-dependent manner with an $\mathrm{IC}_{50}$ of $41.14 \mathrm{mg} / \mathrm{ml}$

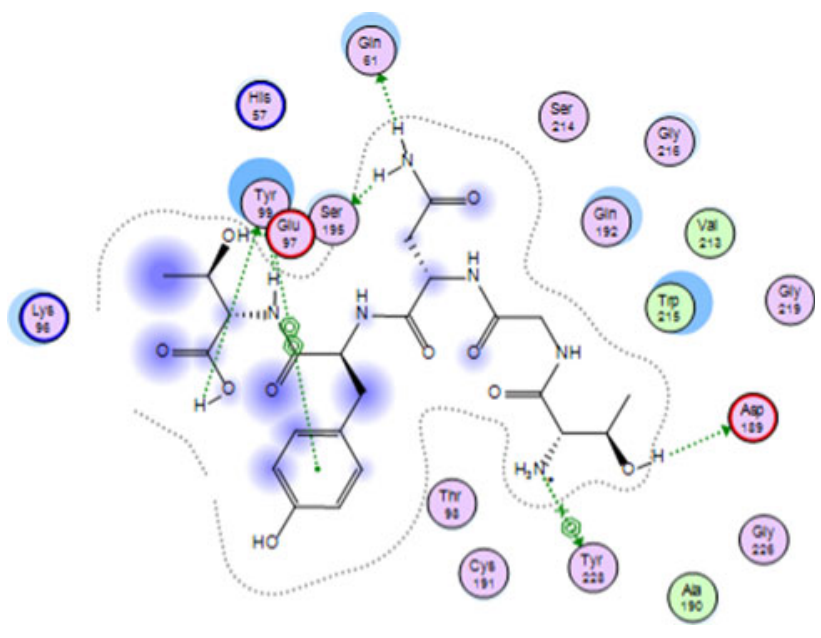

Fig. 5 Molecular docking of TNGYT with FXa. TNGYT bound to Asp189, Ser195 and Tyr228 residues of S1 and Tyr99 residue of S4 of FXa

anticoagulants from five-pace snake (Agkistrodon acutus) venom. Though centipede venom contained varied peptides and proteins, such as antimicrobial peptides (Peng et al. 2010), hemolytic peptide (Ren et al. 2007). To our best knowledge, it is the first peptide identified from $S$. subspinipes mutilans venom with anticoagulant and FXainhibiting activities.

The coagulation cascade is a dynamic and complicated process triggered by endothelial and/or plaque damage and consists of the extrinsic and intrinsic pathways. FXa is a trypsin-like serine protease that sits at the junction of both the extrinsic and the intrinsic pathways. FXa, in combination with its co-factor $\mathrm{Va}$, converts prothrombin to thrombin, the final enzyme produced in the coagulation cascade. Thrombin activates platelets and also converts fibrinogen to fibrin, which leads to clot formation. Thrombin is also known to amplify its own production by activating factor XI to factor XIa which, in turn, leads to a further activation of $\mathrm{FXa}$, thus leading to the further 
propagation of thrombin. Since FXa sits at the critical juncture of both pathways, its role as a regulator of thrombin generation is very critical in controlling the haemostatic network. So, the purified TNGYT could prolong the aPTT and PT both in vitro and ex vivo and whole blood clotting time possibly by the mechanism of inhibition of the FXa activity.

The active site of the FXa is mainly divided into four "pocket": S1, S2, S3, and S4. S1 determines selective binding; S2 is small, and generally studied with S4; S3, located in the edge of $\mathrm{S} 1$, is completely exposed to the solvent environment; There are three ligand-binding domains in S4, named "hydrophobic cartridge (hydrophobic box)", "cationic hole (cationic hole)" and the water point (water site). FXa inhibitor usually binds to Asp189, Ser195 and Tyr228 of S1 and Tyr99, Phe174 and Trp228 of S4 (Rai et al. 2001). TNGYT bound to Asp189, Ser195 and Tyr228 residues of $\mathrm{S} 1$ and Tyr99 residue of S4 mainly by side-chain interaction. Thus, the docking study revealed that TNGYT could inhibit the activity of FXa, but also suggested that the relatedly low potency of this natural peptide may result from its incomplete binding to FXa. Optimization of TNGYT into a drug molecule should aim to complement extra domains for full binding to FXa.

So far, the molecular mass of the known FXa inhibitors which belong to protein and peptide has been more than $5 \mathrm{kDa}$. Ac-AP-12 (Jiang et al. 2011) from the esophageal glands of adult Ancylostoma caninum was a $9.1 \mathrm{kDa}$ anticoagulation peptide with FXa inhibition activity. Amblyomin-X (Batista et al. 2010) was a single-chain protein with the molecular mass of 13,491 Da. Nymphal FXa inhibitor (Ibrahim et al. 2001) isolated from the camel tick Hyalomma dromedarii was a protein with the molecular mass of 15 kDa. FXa inhibitor named AduNAP4 (Gan et al. 2009) with 104 amino acids including a predicted 23-residue signal peptide, was from the human hookworm, Ancylostoma duodenale. The pentapeptide TNGYT in this study was the smallest peptide which could inhibit the activity of FXa. Although it was easier for preparation, the inhibition rate of TNGYT was lower than FXa inhibitors mentioned above. Further modification and transformation are needed to improve the FXa inhibition activity of TNGYT.

We could not rule out other underlying mechanisms that lead to TNGYT actions. Obviously, the peptide showed higher potency in animal studies compared to in vitro assays. At the same dose of $20 \mathrm{mg} / \mathrm{kg}$, TNGYT produced about $50 \%$ of the effects in prolonging the clotting time compared to heparin after i.v. injection to mice, while the potency of the peptide was at least 8-folded lower than heparin with in vitro assay. The superior result from animal studies is encouraging to further develop this natural peptide into drug entity. Nevertheless, it also warrants further mechanism studies to examine the different outcomes from in vitro and in vivo experiments. Animal study is more complicated setting than in vitro assays and it gives opportunities for the drug to interact with endogenous molecules as well as to be transformed chemically. It is possible that TNGYT gains extra potency when interacting with other molecules or being transformed into other molecules in vivo. We do not intend to resolve the mechanism in this first study of this novel peptide, but will focus on the mechanism study in the future.

In conclusion, this is the first report that an FXa inhibiting peptide was isolated from centipedes venom. The activity assay showed this novel peptide of TNGYT can anticoagulate in both in vitro and ex vivo assays and inhibited the activity of FXa in a dose-dependent manner. According to the results of molecular docking, the possible mechanism is that TNGYT binds to four amino acids residues within the active site of FXa.

Acknowledgments This study was supported by The Innovative Plan of Jiangsu Provincial Graduate (No. CXZZ11-0822), Jiangsu Provincial Qing Lan Project, Chinese National Natural Science Foundation (30972822, 81273274, and 81273375).

Conflict of interest No conflict of interest to declare.

Open Access This article is distributed under the terms of the Creative Commons Attribution License which permits any use, distribution, and reproduction in any medium, provided the original author(s) and the source are credited.

\section{References}

Batista IFC, Ramos OHP, Ventura JS et al (2010) A new factor Xa inhibitor from Amblyomma cajennense with a unique domain composition. Arch Biochem Biophys 493:151-156

Dunwiddie C, Thrnberry N et al (1989) Antistasin, a leech-derived inhibitor of Factor Xa. Biol Chem 264:16694-16699

Fernandeza AZ, Tablantea A, Beguin S et al (1999) Draculin, the anticoagulant factor in vampire bat saliva, is a tight-binding, noncompetitive inhibitor of activated factor X. Biochim Biophys Acta 1434:135-142

Gan W, Deng L, Yang C et al (2009) An anticoagulant peptide from the human hookworm, Ancylostoma duodenale that inhibits coagulation factors Xa and XIa. FEBS Lett 583:1976-1980

Gomes A, Datta A, Sarangi B (1983) Isolation, purification, pharmacodynamics of a toxin from the venom of the centipede Scolopendra subspinipes dehaani Brand. J Exp Biol 21:203-207

González-Morales L, Diego-García E, Segovia L et al (2009) Venom from the centipede Scolopendra viridis say: purification, gene cloning and phylogenetic analysis of a phospholipase $\mathrm{A}_{2}$. Toxicon 54:8-15

Han J, You D, Xu X et al (2008) An anticoagulant serine protease from the wasp venom of Vespa magnifica. Toxicon 51:914-922

Ibrahim MA, Ghazy A-H, Maharem TM et al (2001) Factor Xa(FXa) inhibitor from the nymphs of the camel tick Hyalomma dromedarii. Comp Biochem Physiol Part B 13:501-512

Jiang D, Zhan B et al (2011) Ac-AP-12, a novel factor Xa anticoagulant peptide from the esophageal glands of adult Ancylostoma caninum. Mol Biochem Parasitol 177:42-48 
Knysak I, Martins R, Bertim CR (1998) Epidemiological aspects of centipede bites registered in greater S. Paulo, SP, Brazil. Rev Saude Publica 32:514-518

Kong Y, Huang S-L, Shao Y et al (2013) Purification and characterization of a novel antithrombotic peptide from Scolopendra subspinipes mutilans. J Ethnopharmacol 145:182-186

Labute P (2008) The generalized Born/volume integral implicit solvent model: estimation of the free energy of hydration using London dispersion instead of atomic surface area. J Comput Chem 29:1693-1698

Li XY, Han GZ, Zhang SW et al (2004) Effects of veratrum nigrum var. ussuri ense alkaloids on platelet aggregation and time of coagulation and bleeding. Chin Tradit Herb Drugs 11:1269-1272

Liu Z-C, Zhang R, Zhao F et al (2012) Venomic and transcriptomic analysis of centipede Scolopendra subspinipes dehaani. J Proteome Res 11:6197-6212

Majdoub H, Ben Mansour M, Chaubet F et al (2009) Anticoagulant activity of a sulfated polysaccharide from the green alga Arthrospira platensis. Biochimicaet Biophysica Acta 1790: 1377-1381

Mohamed AH, Abu-Sinna G, El-Shabaka HA et al (1983) Proteins, lipids, lipoproteins and some enzyme characterizations of the venom extract from the centipede Scolopendra morsitans. Toxicon 21:371-377

Kogushi M, Matsuoka T, Kawata T et al (2011) The novel and orally active thrombin receptor antagonist E5555 (Atopaxar) inhibits arterial thrombosis without affecting bleeding time in guinea pigs. Eur J Pharmacol 657:131-137

Negrea S, Minelli A (1995) Chilopoda. In: Decu V, Juberthie C (eds) Encyclopedia Bioespeologica, vol 1. Moulis, France, pp 249254

Pemberton RW (1999) Insects and other arthropods used as drugs in Korean traditional medicine. J Ethnopharmacol 65:207-216

Peng K, Kong Y, Zhai L et al (2010) Two novel antimicrobial peptides from centipede venoms. Toxicon 55:274-279
Rai R, Sprengeler PA et al (2001) Perspectives on Factor Xa Inhibition. Curr Med Chem 8:101

Rates B, Bemquerer MP et al (2007) Venomic analyses of Scolopendra viridicornis nigra and Scolopendra angulata (Centipede, Scolopendromorpha): shedding light on venoms from a neglected group. Toxicon 49:810-826

Ren W, Zhang S, Song D et al (2006) Induction, purification and characterization of an antibacterial peptide scolopendrin I from the venom of centipede Scolopendra subspinipes mutilans. Indian J Biochem Biophys 43:88-93

Ren WH, Zhang SQ, Song DX et al (2007) Purification of the haemolytic peptide from the venom of Scolopendra subspinipes mutilans. Acta Zoologica Sinica 53:519-523

Simkhada JR, Cho SS et al (2012) Purification, biochemical properties and antithrombotic effect of a novel Streptomyces enzyme on carrageenan-induced mice tail thrombosis model. Thromb Res 129:176-182

van Wijk EM, Smit JL (1984) A chromogenic micro-assay for factor x-activity. Thromb Res 34:263-268

Waxman L, Smith D et al (1990) Tick anticoagulant peptide is a novel inhibitor of blood coagulation Factor Xa. Science 248:593-596

Wu Y, Li J, Wang J et al (2009) Anti-atherogenic effects of centipede acidic protein in rats fed an atherogenic diet. J Ethnopharmacol 122:509-516

$\mathrm{Xu} \mathrm{X,} \mathrm{Liu} \mathrm{Q} \mathrm{et} \mathrm{al} \mathrm{(2000)} \mathrm{Purification} \mathrm{and} \mathrm{characterization} \mathrm{of}$ anticoagulation factors from the venom of Agkistrodon acutus. Toxicon 38:1517-1528

Yang S, Liu Z, Xiao Y et al (2012) Chemical punch packed in venoms makes centipedes excellent predators. Mol Cell Proteomics 11:640-650

You WK, Sohn YD, Kim KY et al (2004) Purification and molecular cloning of a novel serine protease from the centipede, Scolopendra subspinipes mutilans. Insect Biochem Mol Biol 34:239-250 